\title{
Mevsimlik gezici tarım işçiliğinde tarım aracılığının rolü: Giresun ili fındık örneği
}

\section{The role of agricultural intermediation in seasonal mobile agricultural work: Giresun province hazelnut sample}

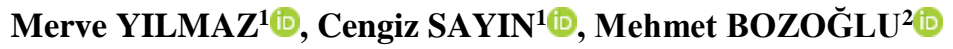 \\ ${ }^{1}$ Akdeniz Üniversitesi, Ziraat Fakültesi, Tarım Ekonomisi Bölümü, 07070, Antalya \\ ${ }^{2}$ Ondokuz Mayıs Üniversitesi, Ziraat Fakültesi, Tarım Ekonomisi Bölümü, 55200, Samsun \\ Sorumlu yazar (Corresponding author): C. Sayın, e-posta (e-mail): csayin@akdeniz.edu.tr \\ Yazar(lar) e-posta (Author e-mail): merveyilmaz@akdeniz.edu.tr, mehmetbo@omu.edu.tr
}

\section{MAKALE BİLGİSİ}

Alınış tarihi 05 Kasım 2020

Düzeltilme tarihi 07 Ocak 2021

Kabul tarihi 19 Nisan 2021

\section{Anahtar Kelimeler:}

Findik

Mevsimlik gezici tarım işçiliği

Tarım aracis1

Giresun

\begin{abstract}
ÖZ
Türkiye'de tarım sektöründe, mevsimlik tarım işçilerinin istihdamında tarım aracıları önemli rol oynamaktadır. Tarım aracısı, işveren ve iş̧̧i iliş̧kileri "Tarımda İș Aracilığı Yönetmeliği" ile düzenlenmiştir. Yönetmeliğe göre tarım aracısı; tarımda iş ve işçi bulma aracıllığı görevini yapmak üzere izin verilen gerçek veya tüzel kişilerdir. Bu çalışmanın amacı; findık tarımında faaliyet gösteren tarım aracılarının çalışma şekillerini, tarım aracısı-işçi-işveren ilişkilerini ortaya koymak ve ilișkileri düzenleyecek öneriler geliștirmektir. Bu çalıșmanın ana materyali; 2015 yılında Giresun ili Merkez, Bulancak, Tirebolu ve Espiye ilçelerinde, kartopu örnekleme yöntemiyle belirlenmiş 29 adet mevsimlik gezici tarım işçisi ve 47 adet işveren ile yüz yüze görüşmeye dayalı anketlerden elde edilmiștir. Araștırma bulgularına göre; tarım aracıları, findık iş̧̧ilerinin günlük yevmiyesi üzerinden \%5-10 arasında değişen oranlarda ücret almaktadır. Ancak ücretin işçiden tahsis edilmesi mevcut yönetmelik hükümlerine uymamaktadır. Mevsimlik gezici işçiler, iş bulma ve ücret garantisi olduğu için tarım aracısı ile çalışmayı tercih etmektedir. Bu bakımdan tarımsal istihdama katkısı önem taşımaktadır. Tarım aracılığı sistemi, sadece mevsimlik iş̧iler için değil aynı zamanda işverenler için de önem arz etmektedir. Ancak uygulamada; aracı, iş̧i ve işveren arasındaki ilişsilerde aksaklıklar olup, bunlar genellikle aracıların denetim eksikliğinden kaynaklanmaktadır. Mevcut tarım aracılığı sisteminin yasal yapılanması, ihtiyacı karşılayacak düzeyde olmasına karşın, uygulamanın daha etkin denetlenmesi ile sorunlar önemli ölçüde çözülebilecektir.
\end{abstract}

\section{ARTICLE INFO}

Received 05 November 2020

Received in revised form 07 January 2021

Accepted 19 April 2021

\section{Keywords:}

Hazelnut

Seasonal migratory agricultural workers Agricultural intermediary

Giresun

\begin{abstract}
In Turkey intermediaries play an important role for employment of seasonal agricultural workers in the agricultural sector. Agricultural intermediary, the employer and worker relations are regulated by the "Regulation on Labor Intermediation in Agriculture". Accordingly, agricultural intermediary are defined as physical persons or legal entities who are allowed to perform employment in agriculture. The aim of this study is to reveal the working methods of agricultural intermediaries operating in hazelnut agriculture, agricultural intermediary-worker-employer relations and to develop proposals to regulate the relations. The main material of this study; in 2015, in the provinces of Giresun Merkez, Bulancak, Tirebolu and Espiye districts, It was obtained from face to face interviews with 29 seasonal migratory agricultural workers and 47 employers, which were determined by the snowball sampling method. According to the research findings; agricultural intermediaries receive 5$10 \%$ of the daily wage of hazelnut workers. However, allocating the wage from the worker does not comply with the provisions of the current regulation. Seasonal migratory agricultural workers prefer to work with an agricultural intermediary; due to there is a guarantee of employment and wages. In this respect, its contribution to agricultural employment is important. The agricultural intermediation system is important not only for seasonal workers it is also for employers. However, in practice; there are disruptions in the relations amongst the intermediaries, the workers and the employers due to the lack of significant inspections of the intermediaries. Although the legal structuring of the current agricultural intermediation system is at a level to meet the needs, Problems can be solved significantly by controlling the application more effectively.
\end{abstract}




\section{Giriş}

Türkiye'de findık üretim alanı 2018'de 728 bin hektar olup bu alanın \%16's1 Giresun ilinde bulunmaktadır. İlin toplam findık üretim miktarı ise 46395 ton olup bu üretim miktarı Türkiye üretiminin \%9'udur (TMO 2019). Bölgede hasat döneminde ihtiyaç duyulan işgücü talebi karşılanamadığından, bölge Ağustos ayında diğer bölgelerden mevsimlik işçi göçü almaktadır. Kayıt dışı çalışma sorunu nedeniyle Türkiye'de mevsimlik gezici ve geçici tarım işçisi sayısı tam olarak bilinmemekle birlikte bazı araştırma bulgularında, 750 bin ve 1 milyon kişi arasında değiştiği ifade edilmektedir (Gülçubuk 2017).

Martin (2016), işgücü piyasalarında işgücü ve işin buluşmasının üç önemli bileşen üzerinden gerçekleştiğini ifade etmektedir. Bunlar "3R" olarak da tanımlanan işe alım (recruitment), ücret (remuneration) ve işte tutmadır (retention) (KA 2018). Mevsimlik tarım işlerinde işgücü ihtiyacı genellikle mevsimlik gezici işçilerden karş1lanmaktadır.

Yaşadıkları yerlerden, tarımsal iş gücü ihtiyacının yoğun olduğu yerlere göç eden bu işçiler genellikle iş bulma, çalışma koşulları, işveren ilişkileri, ücretlendirme ve barınma yeri gibi konularda sorunlar yaşamaktadır (Sayın 2017). Mevsimlik gezici işçiler, bu sorunların çözümünde çoğu zaman yeterli olamadıkları için zorunlu olarak tarımda iş aracılarına ihtiyaç duymaktadırlar. Bu nedenle, işçi ve işveren arasında bir köprü vazifesi gören tarım aracıları, çoğunlukla mevsimlik tarım işçiliğinin yapıldığı bölgelerde faaliyet göstermektedirler. Taşıdığı önem nedeniyle tarım aracılarının görev ve sorumlulukları, dünyada pek çok ülkede olduğu gibi Türkiye'de de yasal düzenlemelerle belirlenmiştir. Örneğin Birleşik Krallık ve Amerika Birleşik Devletleri'nde bu konuda yapılmış olan düzenlemeler dikkat çekmektedir. Birleşik Krallık'ta, 2004'te yayınlanan "Gangmasters Licensing Act" hükümlerine göre, tarım işçiliğinde aracılık yapılabilmesini için ruhsat alınması gerekmektedir (GLA 2004). Amerika Birleşik Devletleri'nde ise "Migrant and Seasonal Agricultural Protection Act" ile göçmen ve mevsimlik tarım işçilerinin korunmasının sağlanması amacıyla işgücü aracılarının kayıt altına alınması gerekliliği ifade edilmiş ve her eyalet için farklı bir federal sertifika istenmiştir (MSPA 1986). Türkiye'de ise tarım aracılarına yönelik görev ve sorumluluklar temel olarak 2010'da uygulamaya giren "Tarımda İş Aracılığı Yönetmeliği" ile belirlenmiştir. İlgili yönetmeliğin hükümleri ile uygulamada karşılaşılan tarım aracılığı işleyiş sisteminin birbirinden çok farklı olduğu gözlenmiştir. Tarım aracılı̆̆ 1 ve mevsimlik işçiler üzerine yapılan diğer çalışmalar ve araştırma raporları da bu gözlemi destekler niteliktedir. Mevsimlik göç alan bölgelerde, mevsimlik işçilik üzerine çok çeşitli araştırmalar yapılmış olmakla birlikte özelde mevsimsel işgücü temininde tarım aracılığı sisteminin işleyişini konu edinen ayrıntılı bir alan araştırması sayısı çok sınırlıdır. Bu çalışmada da konunun önemi dolayısıyla sadece tarım aracılığı konusu findık örneği üzerinden ele alınmış, tartışma bulguları ise alanda yapılan bir araştırma verilerine dayandırılmıştır. Araştırma ile findık hasat döneminde faaliyet gösteren tarım aracılarının, aracılık faaliyetlerinin aracl, işçi ve işveren ilişkileri çerçevesinde incelenmesi, uygulamanın işleyişinin ve karşıllaşılan aksaklıkların belirlenmesi, mevcut sorunların giderilmesi için öneriler geliştirilmesi amaçlanmıştır. Araştırma bölgesinin Giresun ili olarak seçiminde; ilin önemli bir findık üretim bölgesi olması, hasat döneminde (Ağustos) findık işletmelerinin yoğun bir şekilde mevsimlik işçi istihdam etmesi ancak bu ihtiyacın yerel işgücü kaynakları ile karşılanamaması nedeniyle mevsimlik gezici tarım işçisi göçü alması ve bunun da büyük oranda tarım aracılığı ile gerçekleştiriliyor olması etkili olmuştur. Giresun ili kapsamında da, gezici işçilerin en yoğun olduğu Merkez, Bulancak, Tirebolu ve Espiye ilçeleri araştırma alanı olarak belirlenmiştir.

\section{Materyal ve Yöntem}

\subsection{Materyal}

Araştırmanın ana materyalini; Giresun ilinde mevsimlik işçiliğin yoğun talep gördüğ̈̈ bölgeler olan Merkez, Bulancak, Tirebolu ve Espiye ilçelerinde, 2015'de yapılan alan araştırmasından elde edilen birincil veriler oluşturmaktadır. Bu veriler, aynı bölgede yürütülmüş olan "fındık hasadında mevsimlik çocuk işçiliği’" konulu geniş kapsamlı bir araştırmada ayrıca ele alınmış ve bağımsız alt bölüm olarak yürütülmüş olan kısma aittir. Çalışmada ayrıca konuyla ilgili yapılmış çeşitli ikincil veri kaynaklarından da yararlanılmıştır.

\subsection{Metot}

\subsubsection{Veri toplama metodu}

Araştırmanın birincil veri kaynağı olarak; araştırma alanında resmi kayıtlı tarım aracısı bulunmadığından, araştırma alanında bunlarla çalışan mevsimlik gezici tarım işçileri ile aracılarla birlikte çalışan işverenler araştırma konusuyla ilgili veri temininde hedef kitle olarak belirlenmiştir. İşçi ve işveren örnek sayısinın belirlenmesinde ise kartopu (zincir) örnekleme yönteminden yararlanılmıştır. Bir araştırmada evren içerisinde yer alan birimler tam olarak belirlenemez ise popülasyonu temsil edecek örneklemi belirlemek de zorlaşmaktadır. Böyle durumlarda araştırmacı, araştırmada kullanacağı verilere belirli aşamaları takip ederek ulaşmaktadır. Araştırmacının örneklemi adım adım oluşturduğu bu yönteme kartopu örnekleme yöntemi adı verilmektedir. Kartopu örnekleme yönteminde; öncelikle araştırma evreni içerisinde yer alan ve araştırmacının ulaşabileceği ilk birim belirlenmekte, elde edilecek veriler 1şığında sonraki birimlere ulaşılarak mevcut örneklem kartopu şeklinde büyütülmektedir (Kılıç ve Ural 2013). Bu araştırmada, kartopu yönteminin giriş noktası olarak, İl Özel İdare tarafından belirlenen mevsimlik gezici iş̧̧ilerin yerleşim yerleri belirlenmiştir.

\subsubsection{Araştırma alanı}

Giresun ili Merkez, Bulancak, Tirebolu ve Espiye ilçelerindeki mevsimlik işçilerin yoğun olarak konakladı $\breve{g}_{1}$ alanlardan 29 adet gönüllü mevsimlik gezici tarım işçisi ile 47 adet gönüllü işverenle, yüz yüze görüssmeye dayall anket uygulaması gerçekleştirilmiştir.

Aracıların kayıt dışılığı konusu ve işçi-işveren çekimserliği örnek sayısında en önemli sınırlayıcı faktör olmuştur. Ancak kamunun belirlediği alanlarda konaklayan işçilerin yanında olan bazı tarım aracıları ile görüşme cetveli kullanılarak görüşülmüş ve gözlem notlarl oluşturulmuştur. İkincil veriler, kurumların resmi sitelerinden ve ilgili diğer veri tabanlarından arama yapılarak elde edilmiştir. Anket çalışması bölgenin mevsimlik gezici tarım işçisi göçünün en yoğun olduğu dönem olan Ağustos ayında gerçekleştirilmiştir.

\subsubsection{Veri analiz, metodu}

Veriler, "tanımlayıcı istatistik yöntemler" ve "karşılaştırmalı durum analizi", kullanılarak analiz edilmiştir. 
Sonuçlar karşılaştırmalı durum analizi ile değerlendirilmiştir. Araştırma sonucunda elde edilen bulgular; Tarımda İş Aracılığ Yönetmeliği temel esasları ile bunların uygulamaya nasıl yansıdığ 1 konusuna cevap olacak şekilde tartışılmış, noksan ve/veya başarılı olan yönler belirlenerek öneriler geliştirilmiştir.

\section{Bulgular ve Tartışma}

\subsection{Genel Bulgular}

\subsubsection{Mevsimlik tarım işçiliğinde tarım aracılı̆̆ına niçin ihtiyaç duyulmaktadır?}

Fındık hasat döneminde ortaya çıkan yoğun işgücü talebi bölgedeki yerel işçilerden karşılanamamakta, özellikte hasat döneminde bölgeye mevsimlik göç başlamaktadır. $\mathrm{Bu}$ gelişmenin koordinasyonunda tarım aracılarının önemli rolü bulunmaktadır. Çünkü mevsimlik gezici işçilerin işverene ulaşmada yaşadığı zorluk, işverenden ücretlerini alamama ve çalışma/barınma koşulları konusunda işverenle anlaşamama gibi olası sorun alanlarının doğurduğu endişeler ve riskli görülen durumlar, işçilerin tarım aracılarıyla çalışmayı tercih etmelerindeki başlıca nedenlerdir. Diğer yandan işverenler de ihtiyaç kadar ve istenilen zamanda kolay ișçi temin edebildikleri için tarım aracıları ile işçi istihdam etmeyi tercih etmektedirler. Tarım aracısının da arz ve talep buluşmasını sağlayan aracılık hizmeti dolayısıyla ekonomik kazanımları bulunmaktadır. Böylece tarımsal işgücü piyasasında; tarım aracısı, mevsimlik gezici işçi ve işveren ilişkileri ortaya çıkmaktadır. Karaman ve Yılmaz (2011), tarım aracıları bu ilişkilerde önemli rolleri olan kişiler olup öne çıkan başlıca özellikleri aşağıda sıralanmıştır:

- Tarım aracıları, uygulamada işçilerden de işverenden de komisyon almaktadırlar.

- Diğer yandan, bazıları, işverenin ödeme yapmaması durumlarında da bu sorumluluğu üzerine alarak işçilere ödeme yapmak durumunda kalmaktadırlar.

- Beraber çalıştıkları işçilere iş taahhüdünde bulunmakta, iş olmayan zamanlarda ise ihtiyaç halinde onlara kişisel kredi vermekte, işçiler üzerinde karşılıklı onay ile emek ipoteği oluşturmaktadırlar.

\subsubsection{Türkiye'de tarım aracilarının mevcut durumu ve yasal yapıst}

Yapılan alan araştırmalarının çoğu, tarım aracılarının genellikle kayıt dışı çalıştığına işaret etmektedir. Türkiye Büyük Millet Meclisi'nin yayımladığı Mevsimlik Tarım İşçilerinin Sorunlarının Araştırılarak Alınması Gereken Önlemlerin Belirlenmesi Amacıyla Kurulan Meclis Araştırması Komisyonu Raporu'na göre kayıtlı aracı sayısı 726 kişi (Çizelge 1) olup gerçekte bunun daha fazla olduğu tahmin edilmektedir (TBMM 2015).

Türkiye'de tarım aracılığı konusunda öne çıkan iki yasal düzenleme olup bunlar;

a) 19.04.2017 tarih 30043 sayılı Resmi Gazete (RG)'de yayınlanan "Mevsimlik Tarım İşçileri ile Illgili 2017/6 Sayılı Başbakanlık Genelgesi" ve

b) 27.05 .2010 tarih ve 27593 sayılı RG'de yayınlanan

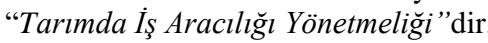

Başbakanlık Genelgesi kapsamında; ilgili kurumların, işverenlerin mevsimlik tarım işçilerini özel istihdam büroları veya İSKUR'a kayıtlı tarım aracıları vasıtası ile istihdam etmeleri için tanıtıcı ve teşvik edici faaliyetler gerçekleştirilmesi gerekliliği ifade edilmiştir (md.13). Tedbirlerin doğru anlaşılması ve uygulanması için, tedbirlerden sorumlu kurum ve kuruluşlarca; göç veren illerde işçiler ve tarım aracılarına, göç alan illerde ise işverenlere ve yöre halkına yönelik bilgilendirme ve bilinçlendirme çalışmalarının yapılacağı belirtilmiştir (md.16) (RG 2017).

Çizelge 1. Kayıtlı tarım aracılarının illere göre dağılımı (TBMM 2015)

Table 1. Distribution of registered agricultural intermediaries by provinces (TBMM 2015)

\begin{tabular}{lclc}
\hline İller & Aracı sayısı (kişi) & İller & Aracı sayısı (kişi) \\
\hline Adana & 140 & Hatay & 16 \\
Amasya & 7 & İzmir & 21 \\
Ankara & 7 & Konya & 51 \\
Aydın & 5 & Manisa & 24 \\
Balıkesir & 17 & Mersin & 129 \\
Bursa & 77 & Şırnak & 6 \\
Çanakkale & 44 & Şanlıurfa & 130 \\
Diyarbakır & 14 & Diğer iller & 26 \\
Eskişehir & 12 & & \\
\hline Genel toplam & & & 726 \\
\hline
\end{tabular}

\subsubsection{Tarımda iş aracılığl yönetmeliği}

Doğrudan tarım aracılığı konusunu ele alan Tarımda İş Aracılığı Yönetmeliği'nde, aracılık konusu daha ayrıntılı olarak ele alınmıştır. Yönetmelikle; tarım aracılığı için izin verilmesi ve bunların çalışma ve denetimi ile tarım aracısı, mevsimlik gezici tarım işçileri ile bunları çalıştıran tarım işverenleri arasındaki ilişsinin düzenlenmesine ilişkin usul ve esasların belirlenmesi amaçlanmıştır (md.2). Yönetmelik kapsamında; tarımda iş/işçi bulma aracılığı (md.5), aracıda aranan nitelikler (md.6), aracı belgesi, süresi, aracı sicili, devri, iptali (md.7-10), yükümlülükler (md.11), sözleşme düzenleme (md.12), rapor verme ve denetleme (md.13-15) gibi konulara ilişkin düzenlemeler getirilmiştir. Yönetmelikte tarım aracısı; "tarımda iş ve işçi bulma aracılığı görevini yapmak üzere IŞSUR'ca izin verilen gerçek veya tüzel kişiler” olarak tanımlanmıştır (md.4). Yönetmeliğin "tarımda iş ve işçi bulma aracılığı" bölümünde; bu işlerin Türkiye İş Kurumu'nca yapılacağı ancak kurum il veya şube müdürlüğü bulunmayan ya da olmasına rağmen haberleşme, ulaşım ve koordinasyon güçlüğü olan yerlerde, kişilere aracılık yapmaları için izin verileceği belirtilmiştir. Yine bu bölümde; kurumdan izin alınmadan aracılık yapılamayacağ 1 ve aracıların hizmet karşıllğı ücretlerini, işçilerden almalarının yasak olduğu ve yalnızca işverenden ücret alınabileceği açıkça belirtilmiştir (md.5).

Yönetmelikte taraflar arasında "yazılı sözleşme" yapılması öngörülerek ücret, çalışma koşulları ve karşılıklı yükümlülüklerin, yazılı sözleşmeyle belirlenmesi zorunlu k1lınmıştır (md.12). Aracıların görevlerini, yönetmelikte bildirilen maddelere uygun olarak yapıp yapmadıkları, İSKUR ile mahalli mülki idare amirlerince denetleneceği ve aykırı davrandığ cezalandırılacağı kararlaştırılmıştır (md.15-16) (RG 2010). 


\subsection{Tarım Aracılarına İlişkin Alan Araştırması Bulguları}

\subsubsection{Tarım aracısı görüşme cetveli bulgular ve alan gözlemleri}

Anket sırasında tarım aracıları ile yapılan görüșmeler ve saha gözlemlerinden elde edilen bulgulardan öne çıkan konular aşağıda sıralanmıştır:

- Aracıllk belgesine sahip herhangi bir tarım aracısına rastlanılmamıştır. Ancak işçilerin aracı olarak göstermiş olduğu kişilerin genellikle İŞKUR kaydı olmayan bir aile büyüğü ya da bir komşusu olduğu anlaşılmıştır.

- Aracılar, aracılık hizmeti karşılığında ücretlerini işçilerin günlük ücreti üzerinden aldıklarını ifade etmişlerdir. İşverenle yaptıkları ücret anlaşmalarında da bu payın göz önünde bulundurulduğu sonucuna ulaşılmıştır.

- Görüşülen aracıların kurumlara aracılık raporu vermediği, işveren ve işçi ile yazılı sözleşme yapmadığı ve herhangi bir denetime tabi tutulmadıkları gözlemlenmiştir.

- Bunun dişında, mevsimlik gezici işçilere; bölgeye ulaşmada, çalışma ve barınma koşullarının belirlenmesinde yardım ettiklerini ve ihtiyaç halinde işçilere borç para verdiklerini belirtmişlerdir.

Benzer şekilde, Aslan ve ark. (2017) tarafından Malatya'da aracılık hizmetleri konusunda yapılan araştırmada, 16 aracı ile görüşülerek işçilerin çalışma bölgelerine ulaşımında önemli oranda aracıların rol oynadığı ve çalışma bölgelerindeki iş durumuna göre işçileri organize ettikleri sonucuna ulaşılmıştır. Yine Malatya'da yapılan çalışmada, bu aracıların aracılık faaliyetleri için izin almadığ 1 ve aracılık belgesinin bulunmadığ belirlenmiştir.

\subsubsection{Mevsimlik gezici findık işçilerinden elde edilen bulgular}

\subsubsection{Mevsimlik gezici işçilerin "iş bulma yöntemlerinde" tarım aracisinin rolü}

Araştırma alanındaki mevsimlik gezici işçilerin büyük çoğunluğu bölgeye Doğu Anadolu ve Güneydoğu Anadolu Bölgesi'nden göç etmiştir. Göç eden işçiler, büyük oranda (\%69) tarım aracıları ile iş bulduklarını ifade etmiştir (Çizelge 2).

Çizelge 2. İşçilerin findık hasadı işini bulma yöntemleri

Table 2. Workers' methods of finding hazelnut harvesting

\begin{tabular}{lcc}
\hline İş bulma yöntemi & Frekans & Oran $(\%)$ \\
\hline Tarım aracısı & 20 & 69.0 \\
$\begin{array}{l}\text { Önce çalıșlan } \\
\text { işletmeyle iletişim }\end{array}$ & 7 & 24.1 \\
$\begin{array}{l}\text { Arazi sahipleriyle } \\
\text { bölgede görüşme }\end{array}$ & 2 & 6.9 \\
\hline Toplam & 29 & 100.0 \\
\hline
\end{tabular}

\subsubsection{Tarım aracısı komisyonu ve işçi ücretlendirmesindeki rolleri}

Araştırma kapsamında, tarım aracısı vasıtasıyla iş bulan işçiler, iş bulma karşılığı olarak aracıya günlük ücret üzerinden \%5-10 arasında komisyon verdiklerini ifade etmişlerdir. Benzer şekilde Kablay (2016) Giresun ve Ordu'da, belge sahibi olmayan çok sayıda aracı bulunduğunu, aracıların işçi ücretleri üzerinden \%10'luk bir pay aldığını ifade etmiştir. İşçilerin, çalışma karşılığı olan ücretlerini aldıkları kişiler Çizelge 3’te gösterilmektedir. Bulgulara göre; tarım aracısı ile çalıştığını ifade eden işçiler (\%69) ücretlerini tarım aracısından alırken diğer işçiler (\%31) işverenden almaktadır.

Çizelge 3. İşçilik ücreti veren kişi

Table 3. The person giving the worker wage

\begin{tabular}{lcc}
\hline Ücreti veren kişi & Frekans & Oran (\%) \\
\hline Tarım aracısı & 20 & 69.0 \\
İşverenin kendisi & 9 & 31.0 \\
\hline Toplam & 29 & 100.0 \\
\hline
\end{tabular}

Tarım aracısı vasıtası ile iş bulan işçilerle ilgili olan; ücretlendirme, ödeme, çalışma ve barınma koşulları gibi konuların işverenle görüşülmesi işlemi tarım aracısı vasıtasıyla yapılmaktadır. Ücretlerin belirlenmesinde tarım aracısı önemli bir rol oynamaktadır. Oysa findık iş̧̧i ücretleri her yıl devlet tarafindan belirlenmekte ve açıklanmasına karşın tarımsal işgücü piyasalarında oluşan ücret, işçinin niteliğine (yaş, geldiği bölge, cinsiyet vb.) göre değişebilmektedir. $\mathrm{Bu}$ farkl111kta işveren tercihlerinin önemli etkisi bulunmaktadır. Tüm bunlara karşın tarım aracısının ücret anlaşmalarındaki rolü göz ardı edilemeyecek düzeydedir. Uygulamada, tarım aracısı ile çalışan mevsimlik işçilerin ücret anlaşmaları, işveren ve tarım aracısı arasında gerçekleştirilmektedir.

Araştırma kapsamında tarım aracısı ile yapılan görüşmelerde, aracının, işçinin günlük ücreti üzerinden komisyon aldığı görülmüştür. İlgili yönetmelik gereği, tarım aracılarının, aracılık hizmeti karşılığı işçiden ücret temin etmesi açıkça yasaklanmış olup aracılık hizmeti ücreti sadece işverenden alınabilecektir. Ayrıca yine yönetmeliğe göre, ücret ödemelerinin aracı üzerinden değil doğrudan çalışan işçiye yapılması gerektiği belirtilmektedir.

\subsubsection{3. İşçi-işveren arasında ücret anlaşmazlığı durumları ve tarım aracısinin rolü}

İşçilerin tarım aracısı ile çalışmayı tercih etmelerinin en önemli nedenlerinden birisi de işçi-işveren arasında ücret konusunda zamanla yaşanmış olan anlaşmazlık durumlarıdır. Nitekim araştırma bulgularına göre de, bölgedeki işçilerin çoğunluğu (\%69) bir anlaşmazlık durumunda sorunlarını tarım aracısı vasıtasıyla çözmeyi tercih etmektedirler. Çok az kısmı ise diğer çözüm yollarına başvurmaktadır (Çizelge 4).

Çizelge 4. Ücret ödeme anlaşmazlığı durumunda başvurulan çözüm yollar1

Table 4. The solutions followed in case of disagreement in wage payment to workers

\begin{tabular}{lcc}
\hline \multicolumn{1}{c}{ Başvurulan çözüm yolları } & Frekans & Oran $(\%)$ \\
\hline Tarım aracısından yardım alma & 20 & 69.0 \\
Zorla almaya çalış̧ma & 2 & 6.9 \\
Konuşarak çözme & 2 & 6.9 \\
Çözümsüz görme & 5 & 17.2 \\
\hline Toplam & 29 & 100.0 \\
\hline
\end{tabular}

\subsubsection{Işverenden elde edilen bulgular}

\subsubsection{1. İsverenlerin "iş̧̧i temininde" tarım aracılarının rolü}

İşverenlerin genellikle tarım aracısı ile çalışmayı tercih etmesinin başlıca nedeni, ihtiyaç duyulan zamanda ve ihtiyac1 kadar sayıda kalifiye ve ucuz işçi temin etmektir. Ancak tarım aracısıyla çalışma tercihi, bulunulan bölgeden veya bölge 
dışından işçi temini durumuna göre değişim göstermektedir. $\mathrm{Bu}$ araştırma kapsamında da findık hasadı için bölgeye gelen işçilerin (29) tamamı Karadeniz Bölgesi dışından olmasına karşın, çalıştıkları işvereni söylemekten kaçınmaları, bu işverenlere ulaşılamaması sonucunu doğurmuştur. Dolayısıyla araştırmaya katılan 47 işveren, kapsamdaki işçilerle çalışan bazı işverenlerin yanında ayrıca zorunlu olarak diğer işverenlerden de seçilerek belirlenmiş ve tarım aracısı ile ilgili sorular sadece işçilerin çalıştığ işverenlere de yöneltilmiştir. Ancak bu durum, tarım aracısını daha az tercih eden işverenlerin de araştırma kapsama alınmasına ve aracı ile çalışma tercihini yapanların oranının düşmesine yol açmıştır. Çünkü pek çok diğer araştırmalarda aracı tercihi yapan işveren oranı daha yüksekken bu araştırmada fındık hasadı işçiliğinde daha düşük kalmıştır. Nitekim araştırma bulgularına göre; işçi temininde tarım aracısı tercih eden işveren oranı \%10.7 olup yakın çevre ilişkilerini kullanarak çevreden işçi bulan işverenlerin toplam oranı (\%89.3) daha yüksek bulunmuştur (Çizelge 5).

Çizelge 5. İşverenlerin tarım iş̧̧isi temin etme yolları Table 5. Employers' ways to find agricultural workers

\begin{tabular}{lcc}
\hline \multicolumn{1}{c}{ İşçi temin yolları } & Frekans & Oran $(\%)$ \\
\hline Akraba, eş, dost vasıtasıyla & 16 & 34.0 \\
Köy ve civarından arama & 15 & 31.9 \\
Daha önce çalışıllan işçileri çağırma & 11 & 23.4 \\
Tarım aracısı vasıtasıyla & 5 & 10.7 \\
\hline Toplam & 47 & 100.0 \\
\hline
\end{tabular}

\subsubsection{Işsverenlerin "ücret belirlemesi ve ödemesinde" tarım aracılarının rolü}

Araştırma kapsamında yer alan işverenlerin büyük çoğunluğu (\%91.5) işçi ücretlerini belirlemede doğrudan işçilerle görüşüp anlaşma yolunu tercih ederken çok az bir kısmı $(\% 8.5)$ tarım aracısı ile işçiler adına anlaşma yolunu tercih etmiştir (Çizelge 6).

Üzerinde anlaşılan ücretlerin ödenmesi aşamasında da farklı aktörler öne çıkabilmektedir. Araştırma kapsamındaki işverenlerin \%57.4'ü ücretleri doğrudan işçilere yaparken \%31.9'u hane reisine \%10.7'si ise tarım aracısına ücret ödemesi yapmıştır (Çizelge 7). Tarım aracısı vasıtasıyla işçi temin eden işverenlerin ödemeleri yine tarım aracısına yaptığı anlaşılmıştır.

Çizelge 6. İşverenlerin işçi ücretlerini belirleme yolları

Table 6. Employers' ways to determine wages of workers

\begin{tabular}{lcc}
\hline Ücret belirleme şekli & Frekans & Oran $(\boldsymbol{\%})$ \\
\hline İşçilerle anlaşma tercihi & 43 & 91.5 \\
Tarım aracısıyla anlaşma tercihi & 4 & 8.5 \\
\hline Toplam & 47 & 100.0 \\
\hline
\end{tabular}

Çizelge 7. İşverenlerin işçi ücreti ödemesi yaptı̆̆ kişiler

Table 7. People with whom employers pay workers' wages

\begin{tabular}{lcc}
\hline Ücret ödemesi yapılan kişiler & Frekans & Oran $(\%)$ \\
\hline İşçinin kendisi & 27 & 57.4 \\
Hane reisi & 15 & 31.9 \\
Tarım aracısı & 5 & 10.7 \\
\hline Toplam & 47 & 100.0 \\
\hline
\end{tabular}

\section{Sonuc}

Tarım aracıları, genellikle bölge dışından yoğun gezici mevsimlik tarım işçiliği talep edilen alanlarda faaliyet göstermektedir. Çalışma bölgesine gelen ve bölgeye yabancı olan gezici işçiler, işverenle önceden yapılan bir yazılı sözleşme olmaması durumunda iş bulma, ücret düzeyi ve ödeme şekli, çalışma, ulaşım ve barınma koşulları, işverenle farklı alanlardaki anlaşmazlık halleri gibi konularda sıkıntılar yaşayabilmektedirler. $\mathrm{Bu}$ nedenle bölge dışından gelen işçiler, riske girmemek için tarım aracısı vasıtası ile çalışmayı daha çok tercih etmektedir. Tarım aracıları, sadece iş̧̧i açısından değil aynı zamanda işveren açısından da bazı avantajlar oluşturmaktadır. İşverenler, iş öncesinde tarım aracıları ile yapılan (çoğunlukla) sözlü veya yazılı anlaşmalarla; yoğun işçi talebi olan dönemler için ihtiyaç duyulan sayı kadar ve piyasaya göre daha düşük düzeyli ücretlerden işçi bulabilme güvencesine kavuşmaktadırlar. Ancak tarım aracıları, yönetmeliğe aykırı olmakla birlikte bu hizmetleri karşılığında tüm işçilerden "aracılık komisyon ücreti" almaktadırlar. Nitekim araştırma kapsamında görüşülen işçilerin \%69'u, tarım aracısı vasıtasıyla iş bulmakta ve araciya, günlük ücretin \%5-10’u arasında komisyon ücreti vermektedirler. Aracılık hizmeti ücretini iş̧̧i yerine işverenden alan bir aracıya da bölgede rastlanılmamıştır. Diğer yandan, bölgede yerleşik olan yerel işçilerin işvereni önceden tanıma durumu nedeniyle tarım aracısı ile çalışma tercihleri yok denecek kadar az düzeydedir. Bazı ailelerin tarım aracısı olarak tanımladıkları kişiler, akraba veya komşu da olabilmektedir. Bunlar, genellikle bölgede daha önce çalışmış kişiler olup yaşadıkları memleketlerinden akraba veya komşu olan çok sayıda insanı çalışma bölgesine getirmektedirler. Bu araştırma kapsamında görüşme yapılan mevsimlik gezici işçilerin (29) istihdam edildiği işletmeyi söylemekten kaçınması, dolayısıyla bu işverenlerin çoğuna ulaşılamaması nedeniyle, araştırma kapsamına alınan 47 adet işverenin sadece \%10.7'si tarım aracısı vasıtasıyla işçi temin ettiğini ifade etmiştir. Bu nedenle işverenlerin \%57.4'ünün ücret ödemesini, yönetmelikte belirtildiği gibi doğrudan çalışan işçiye yaptığ sonucuna ulaşılmıştır. Diğer yandan çoğunlukla aracı kullanan işverenler için bunu söylemek zordur. Tarım aracılı̆̆ yapabilmek için "aracılık belgesi sahibi olma" koşulu yönetmelikte açıç̧a belirtilmiş olmakla birlikte araştırma kapsamındaki bölgede, belgeli aracıya rastlanılmamıştır. Gerçekte gezici mevsimlik işçilik ve tarım aracılığı gibi konularda mevcut yasal düzenlemeler kapsamında uygulamaya ilişkin gerekli önlemler yer almasına karşın belgesiz aracılık ve aracı komisyonu alma gibi yönetmelik dışı bazı sorunlu uygulamaların alandaki denetim eksikliğinden kaynaklandığ düşünülmektedir.

Tarım aracılığı ve gezici mevsimlik tarım işçiliği konularındaki alan denetimleri daha etkin bir hale getirilerek, tarım aracılarını kayıt altına alma konularına daha fazla ağırlık verilmelidir. Tarım aracıları ve işverenler arasında yazılı sözleşme yapılması, aracıların işçiden komisyon ücreti almaması, ücret ödemelerinin doğrudan işçilere yapılması ve ücret düzeyini belirlemede yerel ekonomik koşulların dikkate alınması gibi konulardaki yönetmelik hükümleri uygulamada sıkı takip edilmelidir. İŞKUR ve diğer ilgili kurumların göç alan ve göç veren birimleri arasında bilgi akışı sağlayacak bir işbirliği ağı oluşturulmalıdır. Yönetmeliğe göre, işçilerin ulaşım güvenliği denetimi tarım aracılarının görev tanımında yer almasına karşın Türkiye'de her yıl birçok mevsimlik gezici işçi kötü koşullarda ulaşım yapmakta ve tedbirsizlik nedeniyle ölümle sonuçlanan kazalar yaşanabilmektedir. Mevsimlik 
işçilerin ulaşım güzergâhlarının önceden belirlenerek, güvenli ulaşım için gerekli tedbirlerin alınması ve bu amaçla aracıların etkinliğinin daha da arttırılması olası kazaların önlenmesine yardımcı olacaktır. Mevsimlik gezici tarım işçiliğinde haberleşme, ulaşım ve koordinasyon önemli sorun alanlarıdır. Tarım aracıları bunların çözümünde önemli bir role sahiptirler. Mevcut yasal düzenlemeler, sorunun çözümü için önemli oranda iyileştirme sağlayıcı niteliktedir. Ancak, uygulamadaki farklılıklar, sorunun devam etmesine neden olmaktadır. Teori ve uygulama arasındaki farklılığın giderilmesindeki en önemli faktör denetimdir. Denetim eksikliği, mevcut düzenlemenin yanlış uygulanmasının devamında etkilidir.

\section{Kaynaklar}

Aslan A, Gündüz O, Atay S, Duran Z, Görücü İ (2017) Mevsimlik tarım işçiliğinde aracılık hizmetlerinin mevcut durumu: Malatya örneği. Tarım Ekonomisi Araştırmaları Dergisi 2: 1-6.

GLA (2004) Gangmasters (Licensing) Act. http://www.legislation.gov.uk/ukpga/2004/11/section/1. Erişim 19 Ağustos 2019.

Gülçubuk B (2017) 6331 Sayılı tarımda iş sağlığı ve güvenliği kanunu tarımda çalışanlar için bir şey ifade eder mi?. International Journal of Social Sciences and Education Research 2: 573-582.

KA (2018) Tarım Aracıları ve Türkiye'de Tarımsal Üretimde Çocuk İş̧̧iliği.

http://www.ka.org.tr/dosyalar/file/Yayinlar/Raporlar/TURKCE/07/ TARIM\%20ARACILARI\%20RAPOR\%20_TR.pdf. Erişim 29 Nisan 2018.

Kablay S (2016) Fındık bahçesinde işçi olmak: Ordu ve Giresun illerinde mevsimlik tarım işçilerinin çalışma koşulları. (Ed: Haspolat E, Yıldırım D), Değişen Karadeniz'i Anlamak. Desen Ofset, Ankara, s. 281-308.

Karaman K, Yılmaz AS (2011) Mevsimlik tarım işçileri ve enformel ilişkiler ağı: Giresun'da çalışan mevsimlik tarım işçileri üzerine bir araştırma. Journal of World of Turks 1: 211-226.

Kılıç İ, Ural A (2013) Bilimsel Araştırma Süreci ve SPPS ile Veri Analizi. 4. Bask1. Detay Yayıncılık, Ankara.

Martin PL (2016) Migrant workers in commercial agriculture. https://www.ilo.org/wcmsp5/groups/public/---ed_protect/--protrav/---migrant/documents/publication/wcms_538710.pdf. Erişim 09 Ocak 2019.

MSPA (1986) Migrant and Seasonal Agricultural Protection Act. https://www.dol.gov/agencies/whd/laws-andregulations/laws/mspa. Erişim 17 Şubat 2019.

RG (2010) Tarımda İş Aracılığı Yönetmeliği. Resmi Gazete Tarihi: 27.05.2010, Resmi Gazete Sayıs1: 27593.

RG (2017) Mevsimlik Tarım İş̧̧ileri ile İlgili 2017/6 Sayılı Başbakanlık Genelgesi. Resmi Gazete Tarihi: 19 Nisan 2017. Resmi Gazete Sayisi: 30043.

Sayın C (2017) Tarımda iş hukuku ders notları. (Basılmamış)

TBMM (2015) Mevsimlik Tarım İşçilerinin Sorunlarının Araştırılarak Alınması Gereken Önlemlerin Belirlenmesi Amaciyla Kurulan Meclis $\quad$ Araştırması $\quad$ Komisyonu $\quad$ Raporu. https://www.tbmm.gov.tr/sirasayi/donem24/yil01/ss.716.pdf. Erişim 02 Aralık 2019.

TMO (2019) Findik Sektör Raporu. http://www.tmo.gov.tr/Upload/Document/findiksektorraporu2018.p df. Erişim 07 Mart 2019. 